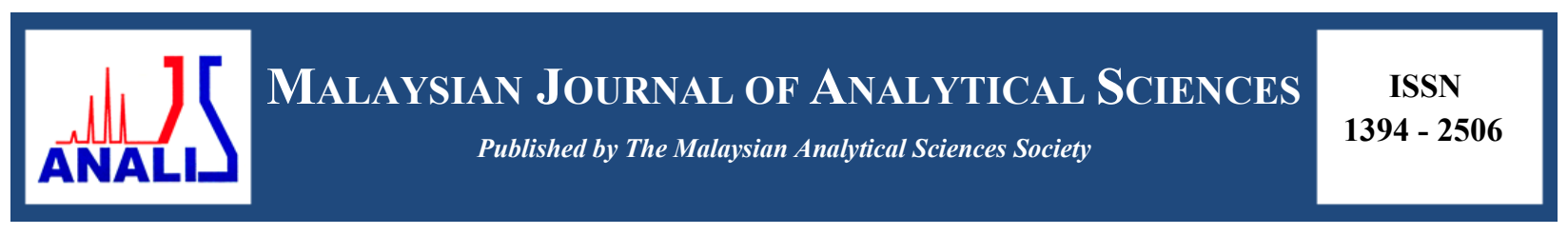

\title{
ISOLATION AND SYNTHESIS OF PINOCEMBRIN AND PINOSTROBIN FROM Artocarpus odoratissimus
}

\author{
(Pemencilan dan Sintesis Pinocembrin dan Pinostrobin dari Artocarpus odoratissimus) \\ Nyotia Nyokat ${ }^{1}$, Khong Heng Yen ${ }^{1 *}$, Ahmad Sazali Hamzah ${ }^{2}$, Isabel Fong Lim³ ${ }^{3}$, Aimi Suhaili Saaidin ${ }^{2}$ \\ ${ }^{1}$ School of Chemistry and Environmental Studies, Faculty of Applied Sciences, \\ Universiti Teknologi MARA, 94300 Kota Samarahan, Sarawak, Malaysia \\ ${ }^{2}$ Institute of Science, \\ Universiti Teknologi MARA, 40450 Shah Alam, Selangor, Malaysia \\ ${ }^{3}$ Department of Paraclinical Sciences, Faculty of Medicine and Health Sciences, \\ Universiti Malaysia Sarawak, 94300 Kota Samarahan, Sarawak, Malaysia \\ *Corresponding author: khonghy@sarawak.uitm.edu.my
}

Received: 21 August 2016; Accepted: 27 July 2017

\begin{abstract}
Artocarpus odoratissimus is native to Borneo and Mindanao Island. In Sarawak, it is locally known as Terap. Previous studies showed Artocarpus species are rich in phenolic compounds, including flavonoids, stilbenoids and arylbenzofurons. The chemical profile of the indigenous plants from Sarawak, such as A. odoratissimus has not been studied intensively and the analyses of medicinal properties have not been explored. Thus, a phytochemical study is carried out on the root extracts of $A$. odoratissimus using various chromatographic methods and it has led to the isolation of two known flavonoids, namely pinocembrin (1) and pinostrobin (2). The structures are identified by comparison of their ${ }^{1} \mathrm{H}$ and ${ }^{13} \mathrm{C}$ NMR data with those reported in the literature. Flavonoid molecule incorporated as multifunctional in the pharmaceutical industry. It has a vast range of pharmacological activities, such as antimicrobial, anti-inflammatory, antioxidant, and anticancer activities. Pinocembrin and pinostrobin which are successfully synthesized with 2-hydroxy,4,6-methoxyacetphenone and benzaldehyde as starting materials were discussed.
\end{abstract}

Keywords: Artocarpus odoratissimus, terap, pinocembrin, pinostrobin

\begin{abstract}
Abstrak
Artocarpus odoratissimus berasal dari Borneo dan Pulau Mindanao. Di Sarawak ia dikenali sebagai Terap. Kajian terdahulu menunjukkan yang spesis Artocarpus kaya dengan sebatian fenolik, termasuk flavonoid, stilbenoid dan arilbenzofuron. Profil kimia tentang tumbuhan yang berasal dari Sarawak, seperti A. odoratissimus masih belum dikaji secara intensif dan analisis tentang khasiat perubatan masih belum lagi diterokai. Oleh itu, kajian fitokimia yang telah dilakukan ke atas krud ekstrak akar A. odoratissimus dengan menggunakan pelbagai kaedah kromatografi telah berjaya memencilkan dua sebatian flavonoid, iaitu pinosembrin (1) dan pinostrobin (2). Bentuk struktur telah dikenal pasti melalui perbandingan data ${ }^{1} \mathrm{H}$ dan ${ }^{13} \mathrm{C}$ NMR dengan kajian literatur. Molekul flavonoid mempunyai pelbagai fungsi di dalam industri farmaseutikal. Ia mempunyai aktiviti farmakologi yang sangat meluas seperti antimikrob, anti-radang, antioksidan, dan antikanser. Pinosembrin dan pinostrobin yang telah berjaya disintesis dengan menggunakan 2-hidroksi,4,6-metoksiasetofenon dan benzaldehid sebagai bahan pemula telah dibincangkan.
\end{abstract}

Kata kunci: Artocarpus odoratissimus, terap, pinosembrin, pinostrobin 


\section{Introduction}

Artocarpus odoratissimus is native to Borneo. It is cultivated in the Philippines and is also found in the wild abundantly in Brunei Darussalam, Sabah and Sarawak [1]. Artocarpus species are used as traditional medicines such as treatment against inflammation, malarial fever, diarrhea, diabetes and tapeworm infection. According to Jagtap and Bapat [2] compounds from Artocarpus species exhibited diverse biological activities including antibacterial, antitubercular, antiviral, antifungal, antiplatelet, antiarthritic, tyrosinase inhibitory and cytotoxicity. Some Artocarpus species are used as traditional medicines. For example Artocarpus odoratissimus (terap) is used by local communities in Sarawak as an antidote against centipede and scorpion stings by applying the ash from the leaves on the wounds, while for treatment of scabies the ash is added with a little amount of coconut oil [3]. Ee et al. [4] reported that the isolation of a new prenylated pyranoflavone derivatives, artosimmin and traxateryl acetate. Artosimmin exhibited significant cytotoxicity against cancer cell lines (HL-60 and MCF-7) and showed antioxidant properties.

Artocarpus species also rich in phenolic compounds, including flavonoids, stilbenoids and arylbenzofurons. Most of the pharmacological effects can be explained by the presence of phenolic compounds [5]. However, there are very few studies on the Artocarpus species from Sarawak, therefore it would be interesting to develop a chemical profile of such Sarawakian species. Thus, a phytochemical study is carried out on the root extracts of Artocarpus odoratissimus using various chromatographic methods and it has led to the isolation of two known flavonoids, namely pinocembrin and pinostrobin.

Pinocembrin is a flavanone, a type of flavonoid. It is an antioxidant found in damiana, honey, and propolis. Pinocembrin is a major flavonoid molecule incorporated as multifunctional in the pharmaceutical industry. Its vast range of pharmacological activities has been well studied including antimicrobial, anti-inflammatory, antioxidant, and anticancer activities. Pinocembrin has potential as a drug to treat cerebral ischemia, neurodegenerative diseases, cardiovascular diseases and atherosclerosis as well as other clinical conditions [6]. Pinocembrin also exhibits various interesting biological activities such as antibacterial [7], antifungal [8] and anti-inflammatory [9], [10]. Furthermore, pinocembrin plays a pivotal role in prevention and cure of various neurodegenerative diseases, such as Alzheimer's disease (AD), Parkinson's disease and other neuronal dysfunctions [11].

Pinostrobin is a potent flavonoid inducer of mammalian phase 2 chemoprotective and antioxidant enzymes [12]. Pinostrobin isolated from Polygonum lapathifolium nodosum could quickly penetrate through cytoplasm to the cellular nucleus of the cultured cells and gives intensive apoptotic response in stimulating leukemic cells in vitro. As such, it may be considered as a good candidate for a leukemia chemopreventic agent [13]. Pinostrobin from Temu Kunci (Kaempferia pandurata Roxb) has anticancer activity againts benzo(a)pyrene-induced fibrosarcoma cancer on mice in vivo [14]. With increasing concentration, pinostrobin caused a gradual leakage, also contributing to breakage of the envelope and virus inactivation. Treatment effect of oral pinostrobin in vivo showed that pinostrobin possesses definite therapeutically effect in the development of lesion score [15].

The interest in the biological properties of pinocembrin and pinostrobin attracted the intense synthetic efforts towards the synthesis of various derivatives compounds. By synthesis we can also save the usage of natural resources of raw material.

\section{Plant materials}

\section{Materials and Methods}

The root of Artocarpus oddoratissimus was collected from Kampung Krokong Pisa, Bau Sarawak. Voucher specimen of the plant is kept in the School of Chemistry and Environmental Studies, Faculty of Applied Sciences at the Universiti Teknologi MARA (UiTM) Kota Samarahan 2 Campus, Sarawak, Malaysia.

\section{Extraction and isolation}

The air-dried root (722.14 g) of Artocarpus odoratissimus was extracted by a cold extraction method for 24 hours and repeated thrice using n-hexane, ethyl acetate and methanol as solvents. The removal of solvents under reduced pressure gave hexane (AORH), ethyl acetate (AOREA), and methanol (AORM) crude extracts respectively. The crude extracts were fractionated using silica gel vacuum liquid chromatography (VLC) with a stepwise gradient 
solvents system such as hexane, hexane-ethyl acetate, ethyl acetate-methanol and methanol, followed by column chromatography to give major fractions. Fractions with spots of the same $\mathrm{R}_{\mathrm{f}}$ values were combined and rechromatographed in appropriate solvent systems until pure isolates were obtained. The crude ethyl acetate root afforded two known flavonoids namely pinocembrin (1) and pinostrobin (2) (Figure 1)
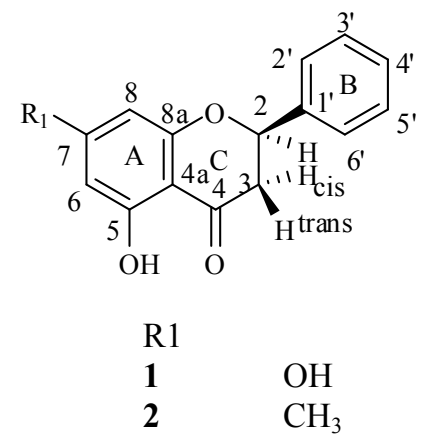

Figure 1. Structure of compounds (1-2) isolated from A. odoratissimus

\section{Synthesis of pinocembrin and pinstrobin: Synthesis of 2-hydroxy-4,6-dimethoxychalcone via Claisen-Schmidt condensation}

$20 \%$ of aqueous $\mathrm{KOH}(2 \mathrm{mmol})$ was added to a solution of benzaldehyde (4 mmol) and 2-hydroxy-4,6dimethoxyacetophenone $(4 \mathrm{mmol})$ in $\mathrm{C}_{2} \mathrm{H}_{5} \mathrm{OH}(25 \mathrm{~mL})$. The reaction mixture was stirred at room temperature untill completion of reaction (monitored by TLC). The reaction mass was then poured into ice water and neutralized with aqueous $10 \% \mathrm{HCl}$ solution. The precipitate was filtered, washed with excess of water, dried and recrystallized from methanol to obtain pure 2-hydroxy-4,6-dimethoxy chalcones.

\section{Synthesis of flavonol}

A suspension of a mixture of powdered 2-hydroxy-4,6-dimethoxychalcone $(0.10 \mathrm{~g}, 0.45 \mathrm{mmol})$ in EtOH, an aq. $\mathrm{NaOH}$ solution $(8 \mathrm{M}, 1.0 \mathrm{ml})$ and a $30 \%$ hydrogen peroxide solution $(0.25 \mathrm{~g})$ was stirred at room temperature for 2 hours. The crude product was filtered off, washed with water to give flavonol (Scheme 1). Recrystallization of the crude product from $\mathrm{MeOH}$ gave pure compound.
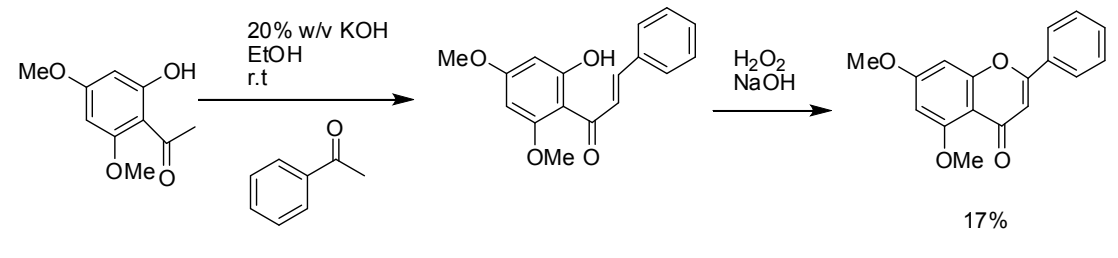

Scheme 1. Formation of flavonol

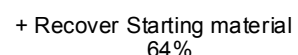

\section{Scheme 1. Formation of flavonol}

Formation of flavanone via hydrogenation reaction

The reaction involves hydrogenation of flavonol to form flavanone (Scheme 2).

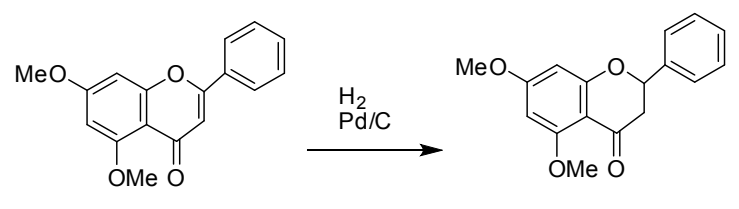

Scheme 2. Formation of flavanone 


\section{Demethylation of aryl methyl ethers}

To a solution of aryl methyl ether $(1.0 \mathrm{mmol})$ in $[\mathrm{BMIM}] \mathrm{BF}_{4}(2 \mathrm{~mL})$ was added magnesium iodide $(0.42 \mathrm{~g}, 1.5$ mmol). The reaction mixture was stirred at $50{ }^{\circ} \mathrm{C}$ for $4-7$ hours. After addition of $5 \%$ aqueous sodium thiosulfate $(10 \mathrm{~mL})$, the product was extracted with ether $(2 \times 10 \mathrm{~mL})$, washed with brine $(5 \mathrm{~mL})$, and extracted with ether $(2 \times$ $10 \mathrm{~mL}$ ), washed with brine $(5 \mathrm{~mL})$, and dried over $\mathrm{MgSO}_{4}$. The solvent was removed in vacuo and the crude mixture was purified by silica gel chromatography using ethyl ether: hexane (1:3) as eluent to give the desired phenolic product (Scheme 3).

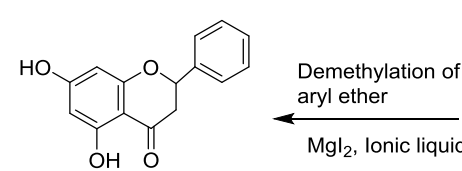

Pinocembrin

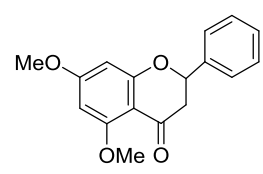

OMe O

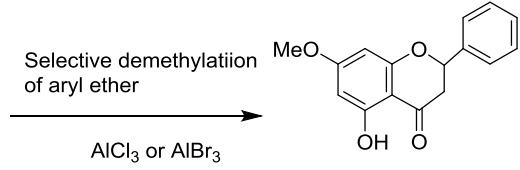

Pinostrobin

Scheme 3. Formation of phenolic product

\section{Results and Discussion}

The extraction and separation from the root extract of Artocarpus odoratissimus, afforded two flavonoids, which were identified and characterized as pinocembrin (1) and pinostrobin (2) based on data comparison literature.

\section{Characterization study: Pinocembrin (1)}

White yellowish crystalline; $\mathrm{mp} 201-202{ }^{\circ} \mathrm{C}$; IR $(\mathrm{KBr}) v_{\max } \mathrm{cm}^{-1}: 3435$ (Ar-H stretching), 1744 (C=O ester), 1497, $1578\left(\mathrm{C}=\mathrm{C}\right.$ Aromatic), $1248(\mathrm{C}-\mathrm{O})$ and $976(=\mathrm{C}-\mathrm{H}) \mathrm{cm}^{-1}$; EI-MS m/z (\% rel. int.); $256(100)\left[\mathrm{M}^{+} \mathrm{C}_{15} \mathrm{H}_{12} \mathrm{O}_{4}\right], 238$ (14), 179 (70), 152 (80), 124 (45), 104 (18), 77 (20), 69 (20) and 51(9); ${ }^{1} \mathrm{H}$ NMR (400 MHz; $\mathrm{CDCl}_{3}$ ): $\delta 2.86$ (3-cis), 3.10 (3-trans), 5.43 (2H, t, J=6.7), $6.03(\mathrm{H}-6), 6.03(\mathrm{H}-8), 7.41-7.49$ (H-2'-H6'), 12.07 (C-5-OH). ${ }^{13} \mathrm{C}$ NMR (100 $\mathrm{MHz} ; \mathrm{CDCl}_{3}$ ): $\delta 43.37(\mathrm{C}-3), 79.18(\mathrm{C}-2), 95.56(\mathrm{C}-8), 96.81$ (C-6), 102.97 (C-4a), 126.16 (C-2', C-6'), 128.87 (C3', C-4', C-5'), 138.42 (C-1'), 163.11 (C-8a), 164.34 (C-5), 195.65 (C-4).

\section{Pinostrobin (2)}

Colorless crystal; $\mathrm{mp} 100-102{ }^{\circ} \mathrm{C}$; IR (KBr) $v_{\max } \mathrm{cm}^{-1}$ : 3467 (Ar-H stretching), $1741(\mathrm{C}=\mathrm{O}$ ester), 1497, $1578(\mathrm{C}=\mathrm{C}$ Aromatic), 1538, $1360(\mathrm{C}-\mathrm{O})$ and $968(=\mathrm{C}-\mathrm{H}) \mathrm{cm}^{-1}$; EI-MS m/z (\% rel. int.); 270 (90) $\left[\mathrm{M}^{+} \mathrm{C}_{16} \mathrm{H}_{14} \mathrm{O}_{4}\right], 269$ (50), 252 (8), 193 (100), 166 (80), 138 (50), 110 (18), 95 (35), 78 (15) and 51 (20);. ${ }^{1} \mathrm{H}$ NMR (400 MHz; $\mathrm{CDCl}_{3}$ ): $\delta 2.81$ (3cis), 3.86 (C-7-OMe), 3.10 (3-trans), 5.43 (2H, t, J=6.7), 6.03 (H-8), 6.04 (H-6), 7.28-7.49 (H-2'-H6'), 12.07 (C-5$\mathrm{OH}) .{ }^{13} \mathrm{C}$ NMR $\left(100 \mathrm{MHz} ; \mathrm{CDCl}_{3}\right): \delta 43.36$ (C-3), 55.60 (C-7-OMe), 79.25 (C-2), 95.49 (C-6, C-8), 103.20 (C-4a), 126.17 (C-2', C-6'), 128.92 (C-3', C-4', C-5'), 138.30 (C-1'), 163.16 (C-5), 164.36 (C-7), 164.63 (C-8a), 195.79 (C-4).

Compound (1) was obtained as white yellowish crystalline with melting point $201-202{ }^{\circ} \mathrm{C}$. The mass spectrum showed the molecular ion peak at $\mathrm{m} / \mathrm{z} 256$, indicated the formal formula $\mathrm{C}_{15} \mathrm{H}_{12} \mathrm{O}_{4}$. In the ${ }^{1} \mathrm{H} \mathrm{NMR}$, one proton singlet at $\delta 12.07$ sited the free hydroxyl at position 5 with $\mathrm{H}$-bridge to $\mathrm{O}$ at the carbonyl at position 4 . Two doublets at $\delta 6.03$ attributed to meta H-6 and H-8. A five-proton multiplet at $\delta 7.41-7.49$ confirmed the non-substitution of the B-ring. Two doublet-doublet of one proton each at $\delta 2.86$ and $\delta 3.10$ attributable to $\mathrm{H}-3$ (cis) and H-3(trans), respectively. The ${ }^{13} \mathrm{C}$ NMR spectrum showed 15 carbons signals including one methylene, eight methine and six quaternary carbon atoms.

Compound (2) was obtained as colorless crystal with melting point $100-102{ }^{\circ} \mathrm{C}$. The mass spectrum showed the molecular ion peak at $\mathrm{m} / \mathrm{z} 270$ indicating that the compound had the formula $\mathrm{C}_{16} \mathrm{H}_{14} \mathrm{O}_{4}$. The IR spectrum showed the presence of aromatic stretch at $3467 \mathrm{~cm}^{-1}$, carbonyl group, ester $(\mathrm{C}=\mathrm{O})$ at $1741 \mathrm{~cm}^{-1}$ as well as an olefin functional group (C-O) at $1538 \mathrm{~cm}^{-1}$. In the ${ }^{1} \mathrm{H}$ NMR, a methoxy group was seen as a singlet at $\delta 3.86$. A one-proton singlet at $\delta 12.07$ sited the free hydroxyl at position 5 with $\mathrm{H}$-bridge to $\mathrm{O}$ at the carbonyl at position 4 . The ${ }^{13} \mathrm{C}$ NMR 
spectrum showed 16 carbons signals including one methyl, one methylene, 8 methine and 6 quaternary carbon atoms. Among these signals the carbon signal of methoxy group is clearly assigned due to the presence of chemical shift 55.60 .

The Claisen-Schmidt condensation of 2-hydroxy-4,6-dimethoxyacetophenone with benzaldehyde under basic condition $(\mathrm{KOH} 50 \%)$ in ethanol proceeded smoothly to furnish 2-hydroxy-4,6-dimethoxychalcone in excellent yield, (97.1\%). The cyclisation of 2-hydroxy-4,6-dimethoxychalcone in ethanol and aqueous sodium hydroxide solution and a 30\% hydrogen peroxide solution gave flavonol and the hydrogenation of flavonol produced flavanone. The reaction of aryl methyl ether and magnesium iodide gave pinocembrin and with aluminum trichloride gave pinostrobin as product.

\section{Conclusion}

The isolation of Artocarpus odoratissimus root extract had successfully led to two known flavonoids, namely pinocembrin and pinostrobin. These compounds were then successfully synthesized with 2-hydroxy-4,6dimethoxyacetphenone and benzaldehyde as starting materials. The identification of compounds was carried out using spectroscopic methods: Infrared (IR) spectroscopy, Nuclear Magnetic Resonance (NMR) spectroscopy and Gas Chromatography Mass Spectroscopy (GC-MS) and a comparison with the literature data of compound.

\section{Acknowledgment}

The authors would like to acknowledge the financial assistance provided by the Ministry of Higher Education, under Research Grant of (600-RMI/TRGS 5/3/(1/2014)-2) and (600-RMI/RAGS 5/3 (95/2013). The authors also extended their thanks to Research Management Institute, Universiti Teknologi MARA (UiTM), Malaysia for their excellent support and assistance.

\section{References}

1. Subhadrabandhu, S. (2001). Under-utilized tropical fruits of Thailand (English): Thailand. Regional Office for Asia and the Pacific.

2. Jagtap, U. B. and Bapat, V. A. (2010). Artocarpus: a review of its traditional uses, phytochemistry and pharmacology. Journal of Ethnopharmacology, 129(2): 142 - 166.

3. Chai, P. K. (2006). Medicinal plants of Sarawak. Lee Ming Press, Kuching: pp. 212.

4. Ee, C. L. G., Teo, S. H., Rahmani, M., Lim, K. C., Lim, M. Y. and Bong, F. J. C. (2010). Artosimmin-a potential anti-cancer lead compound from Artocarpus odoratissimus. Letters in Organic Chemistry 7(3): $240-$ 244.

5. Hakim, E. H., Achmad, S. A., Juliawaty, L. D., Makmur, L., Syah, Y. M., Aimi, N., Kitajima, M. and Ghisalberti, E. L. (2006). Prenylated flavonoids and related compounds of the Indonesian Artocarpus (Moraceae). Journal of Natural Medicine, 60: 161 - 184.

6. Liu, R., Li, J. Z., Song, J. K., Zhou, D., Huang, C., Bai, X. Y., Xie, T., Zhang, X., Li, Y. J., Wu, C. X. and Zhang, L. (2014). Pinocembrin improves cognition and protects the neurovascular unit in Alzheimer related deficits. Neurobiology of Aging 35(6): 1275 - 1285.

7. Drewes, S. E. and van Vuuren, S. F. (2008). Antimicrobial acylphloroglucinols and dibenzyloxy flavonoids from flowers of Helichrysum gymnocomum. Phytochemistry, 69(8): 1745 - 1749.

8. López, A., Ming, D. S. and Towers, G. N. (2002). Antifungal activity of benzoic acid derivatives from Piper lanceaefolium. Journal of Natural Products, 65(1): $62-64$.

9. Sala, A., Recio, M. C., Schinella, G. R., Máñez, S., Giner, R. M., Cerdá-Nicolás, M. and Ríos, J. L. (2003). Assessment of the anti-inflammatory activity and free radical scavenger activity of tiliroside. European Journal of Pharmacology, 461(1): $53-61$.

10. Arslan, S., Ozbilge, H., Kaya, E. G. and Er, O. (2011). In vitro antimicrobial activity of propolis, BioPure MTAD, sodium hypochlorite, and chlorhexidine on Enterococcus faecalis and Candida albicans. Saudi Medical Journal, 32(5): 479 - 483.

11. Essa, M. M., Vijayan, R. K., Castellano-Gonzalez, G., Memon, M. A., Braidy, N. and Guillemin, G. J. (2012). Neuroprotective effect of natural products against Alzheimer's disease. Neurochemical Research 37(9): 1829 1842. 
12. Fahey, J. W. and Stephenson, K. K. (2002). Pinostrobin from honey and Thai ginger (Boesenbergia pandurata): A potent flavonoid inducer of mammalian phase 2 chemoprotective and antioxidant enzymes. Journal of Agricultural and Food Chemistry, 50(25): 7472 - 7476.

13. Smolarz, H. D., Mendyk, E., Bogucka-Kocka, A. and Kockic, J. (2006). Pinostrobin-an anti-leukemic flavonoid from Polygonum lapathifolium L. ssp. nodosum (Pers.) Dans. Zeitschrift für Naturforschung C 61(1-2): $64-68$.

14. Adi Parwata, O., Sukardiman, S. and Widhiartini, A. (2014). Isolasi dan aktivitas antikanker pinostrobin dari Temu Kunci (Kaempferia pandurata Roxb) terhadap fibrosarkoma mencit hasil induksi benzopiren. Journal of Chemistry 8(2): $243-250$.

15. Wu, N., Kong, Y., Zu, Y., Fu, Y., Liu, Z., Meng, R. and Efferth, T. (2011). Activity investigation of pinostrobin towards herpes simplex virus-1 as determined by atomic force microscopy. Phytomedicine, 18(2): $110-118$. 